\section{Использование техники плетения из природных \\ материалов в искусстве ленд-арт}

Using of weaving technique with natural materials in land-art

Ольга Гальчинская, аспирантка, ассистент кафедры рисунка и живописи;

Елена Васильева, канд. техн. наук, доцент кафедры дизайна;

Калина Пашкевич, докт. техн. наук, профессор, профессор кафедры дизайна,

Киевский национальный университет

технологий и дизайна, Украина

\section{CZU: 745/746}

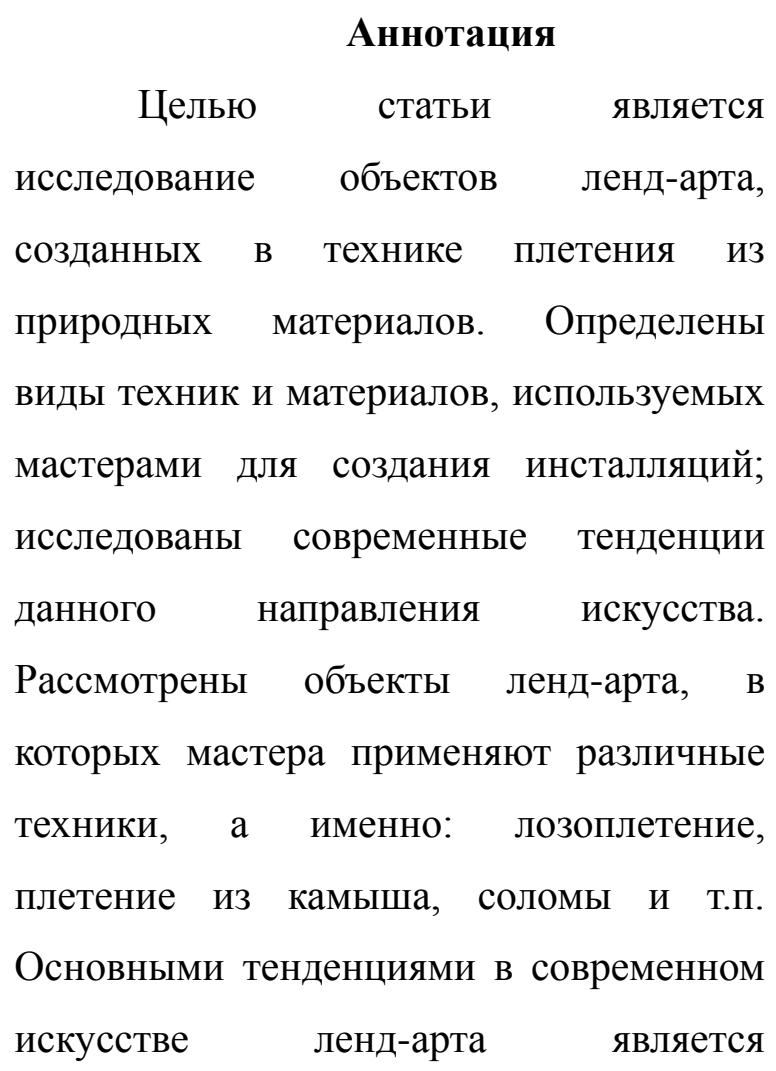

использование

экологических, натуральных материалов, воспроизведение этнических техник и способов создания арт-объектов.

Ключевые слова: искусство, экология, экодизайн, культура, ленд-арт, плетение.

\section{Abstract}

The purpose of the article is to study land-art objects created using the weaving technique from natural materials; the types of techniques and materials used by artists to create installations are identified. The modern trends of this direction of art are investigated. Artists use for land-art objects various techniques: weaving, reed weaving, straw weaving etc. The main trends in modern land-art are the use of environmental, natural materials, reproduction of ethnic techniques and methods create art objects.

Keywords: art, ecology, ecodesign, culture, land-art, weaving.

Ленд-арт, как направление в искусстве, возник во второй половине XX века. Данное направление имеет глубокие корни и широкий диапазон первоисточников, среди которых декоративно-прикладное искусство. Мастера ленд-арта для создания своих работ используют природные материалы, элементы ландшафта, природные явления 
и окружающую среду. При реализации творческих замыслов мастера прибегают к различным приёмам и техникам, среди которых широко используются элементы экостиля с использованием экологически чистых природных материалов. Часто дизайнеры и художники в своих работах обращаются к народному искусству, традиционным этническим мотивам как к источнику вдохновения, а именно: использование стилистических, декоративных и формообразующих приемов народного творчества и художественных ремесел в произведениях ленд-арта.

Понятие ленд-арта и анализ творчества ведущих мастеров и дизайнеров этого направления XX века исследованы авторами О.С. Гальчінська, К.О. Гамалія, К.Л. Пашкевич [1]. Комплексные исследования использования этнических традиций при создании объектов дизайна выполняются учеными в разных странах. В частности, концептуальные основы этно-дизайна в Украине исследует И. А. Сиваш [2]. Рассматривают определенные разновидности техник и свойства материалов декоративно-прикладного искусства Н. Литвинчук [4], И. Ф. Саенко [7]. Анализ тенденций развития искусства ленд-арт выполнен М. Тафалла [3]. С основными концепциями и творческими подходами к искусству ленд-арт знакомят персональные сайты мастеров [5; 6; 13]. Материалы международных симпозиумов и фестивалей искусства ленд-арт представлены в каталогах и на электронных pecypcax $[9 ; 10 ; 15]$. Проблематика ленд-арта, как направления в искусстве, довольно широко исследована во многих работах современных ученых. Однако, данное направление интенсивно развивается, постоянно дополняясь новыми творческими приемами создания объектов ленд-арта и разнообразными техниками. В связи с этим данное направление искусства требует дополнительных исследований.

Целью исследования является анализ опыта использования различных техник плетения для создания объектов ленд-арта, определение основных творческих приемов, которые применяют мастера в своих проектах.

Тенденции обращения к художественному наследию в значительной степени обусловлены использованием техник народного творчества как источников историкокультурных традиций. В современном мировом художественном пространстве возрождается интерес к национальному наследию традиций разных народов. Термин этно-дизайн применяют для 
определения вида, жанра, продуктов или процессов дизайнерской деятельности, в которых использованы определенные формообразующие элементы, принципы или символы, заимствованные из народного декоративно-прикладного искусства [3]. Дизайнеры и художники сегодня часто обращаются к этнотематике, переосмысливая национальные мотивы в архитектуре, предметах быта, произведениях изобразительного и декоративно-прикладного искусств [2, с. 416]. Украина также богата народными традициями и памятниками декоративноприкладного искусства, различными аутентичными техниками изготовления и отделки изделий народного творчества. Мастера продолжают применять старинные техники для разработки современных произведений. Наиболее распространенными техниками народного творчества, которые используют мастера ленд-арта, являются плетение из лозы, соломы, вырезание и другие.

Одной из популярных техник является лозоплетение, что объединяет различные способы создания предметов быта из длинных гибких прутьев ивы, орешника, стеблей камыша, ситника, рогозы, липового лыка, ротанга и т.п., которые предварительно заготавливаются мастерами для работы. Это наиболее распространенная техника декоративноприкладного искусства, дошедшая до наших дней практически в первозданном виде и имеющая широкое распространение на территории Украины, Молдовы, Беларуси и других стран. Для этой техники существует несколько видов материалов и технологий их обработки. Например, иву заготавливали и обрабатывали поразному, в зависимости от того, какое сырье хотели получить: с корой «серую» - или без коры - «белую» лозу [4, с. 69]. Таким образом, плетеное из лозы изделие может иметь различную фактуру и цвет, что даёт художнику широкий спектр возможностей для реализации творческого замысла.

Традиционно в технике плетения из лозы народными мастерами создавались различные предметы быта: малые архитектурные формы, элементы интерьера, мебель, корзины, горшки, вазоны, люльки для младенцев, элементы одежды, аксессуары, посуда, игрушки и т.д. (табл. 1). 
Таблица 1. Традиционные изделия в технике лозоплетения

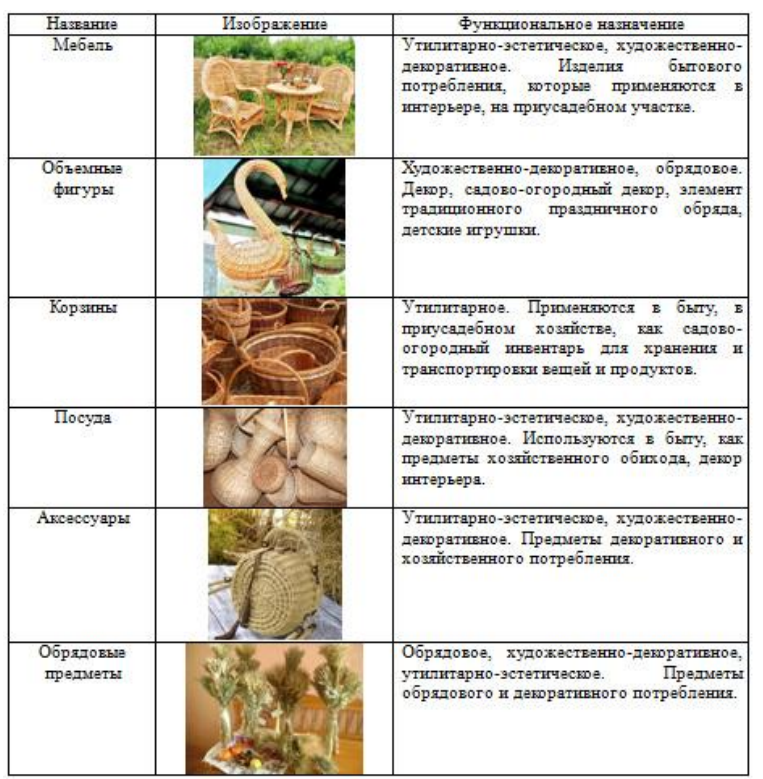

Техника плетения широко применялась не только для создания бытовых предметов широкого потребления (предметов интерьера, элементов одежды, мебели, кровли, жилья, игрушек), а и обрядовых предметов (Рождественского дидуха, чучела на Масленицу, на Ивана Купала, жаворонков, оберегов, венков).

Технику лозоплетения широко используют для создания арт-объектов мастера ленд-арта во многих странах, как в частной художественной практике, так и для различных фестивалей, пленэров и творческих симпозиумов.

$$
\text { Среди мастеров, которые }
$$
используют традиционные этнические техники, известна Анна Энд Уиллоу
(Anna \& the Willow), Великобритания [5]. Основной техникой для создания объектов ленд-арта художница выбрала лозоплетение. В качестве материала она использует лозу различного происхождения, цвета и обработки, за счет чего работы имеют различный характер. Например, ленд-арт «Конь» (г. Йоркшир, Великобритания, 2019 г.) выполнен в натуральную величину, с подробным анализом форм и соблюдением пропорций живого коня (рис. 1, а). Материалом служила лоза темного цвета, которая имеет блестящую кору, что позволило передать эффект блеска шкуры настоящего коня. Этот объект ленд-арта удачно вписан дизайнером в окружающую среду. Одним из самых известных произведений Анны Энд Уиллоу считается «Охотница», созданная в лесах Скиптонского замка (г. Йоркшир, Великобритания, 2018 г.). Этот арт-объект органично вписался в среду, так как «Охотница» расположена вдоль тропы и держит в руках охотничий лук, направленный в лес, будто застыла в движении, натянув невидимую тетиву и подготовившись к выстрелу (рис. 1, б). За счет удачного технического приема плетения лозы по спирали вдоль направления рук и поворота фигуры возникает эффект ее движения, а размер, который в полтора раза превышает рост 
человека,

придает

произведению монументальности.

Мастер из Дании Уил Беккерс (Will Beckers) создает арт-объекты из лозы, встроенные в специфику ландшафта. Концепция данных произведений заключается в том, что мастер лишь временный автор, а основной создатель - природа, которая должна завершить замысел мастера, например, заплести объект диким плющом, или создать ленд-арт, который служит не только эстетическим объектом, а и домом для лесных животных и насекомых [6]. Среди его известных ленд-арт проектов в технике лозоплетения можно выделить работу «Вырастая из деревьев» (Growing into the trees) (парк Босланд, г. Лимбург, Бельгия, 2011 г.), которая олицетворяет большое гнездо, оплетеное основой вокруг деревьев, как вихрь и, собственно, по замыслу мастера растет из них (рис. 1, в). Данный объект расположен около входа в лес, вдоль велодорожек, приглашая зрителей пройтись вдоль и заглянуть вовнутрь леса.

Одним из самых масштабных проектов В. Беккерс является «Проект Вилоумен» (The Willowman project), созданный для фестиваля Floriade (г. Венло, Нидерланды, 2012 г.), после которого автор получил творческий

псевдоним Willowman - человек-ива. Этот проект ленд-арта создан в форме жизненной среды, где в течение шести месяцев жил и работал В. Беккерс. Концепция ленд-арта - взглянуть на природу совершенно по-новому, воссоединиться с ней. Посетителям этого ленд-арт объекта было предложено отказаться от гаджетов, чтобы достичь эффекта замены современных технологий общением с природой [6]. Посетители проекта Willowman, войдя в лес, становятся частью инсталляции, которая приобретает собственную жизнь и создает естественный эко-центр. Таким образом, мастер создал эко-среду, обращаясь к первоначальному восприятию человеком природного мира (рис. 1, г).

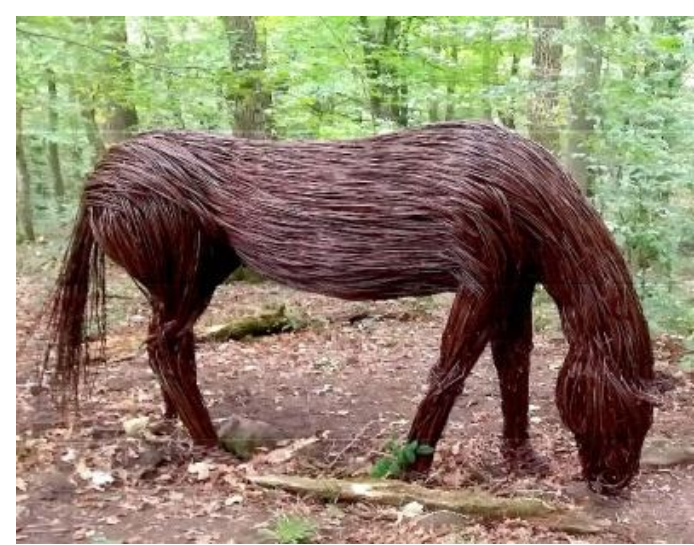



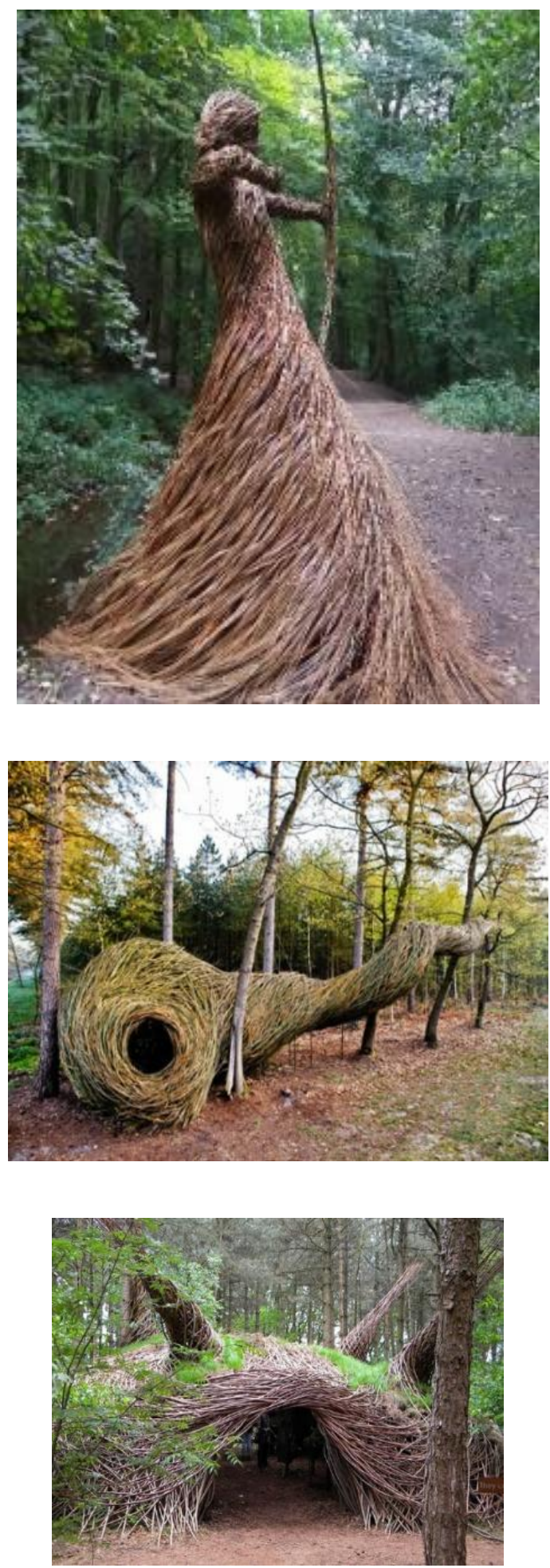

Рис. 1. Объекты ленд-арт в технике лозоплетения: a - «Конь», А. Уиллоу, г. Йоркшир, Великобритания, 2019 г.; б - «Охотница», А. Уиллоу, г. Йоркшир, Великобритания, 2018 г.; в -
«Вырастая из деревьев», У. Бекерс, г. Лимбург, Бельгия, 2011 г.; г - «Проект Вилоумен», У. Бекерс, г. Венло, Нидерланды, 2012 г.

Среди украинских мастеров лендарта, создающих работы в технике лозоплетения, следует отметить творческий дуэт Владимира Балибердина и Галины Дюговской, которые работают с лозой с 2004 года и за этот период создали огромный задел авторских лендартов на территории Украины и за рубежом. Также мастера вместе с Татьяной Мысковец были инициаторами и кураторами международного ленд-арт фестиваля «Диалог с природой», который проходил на протяжении 10 лет в г. Киеве, Украина [8]. Следует отметить, что творческий дуэт В. Балибердина и Г. Дюговской номинирован несколькими международными и украинскими наградами за произведения ленд-арта. Одной из первых и наиболее знаковых работ мастеров является «Эволюция» (дендропарк г. Болестрашице, Польша, 2005 г.) (рис. 2, а) [9, с. 44]. Ленд-арт представляет собой композицию, центром которой является фигура большой птицы, расправившей крылья, а вокруг неё на камнях по спирали расположены по высоте роста абстрактные фигуры, сплетенные из лозы, символизирующие определенные 
трансформации птицы в процессе эволюции.

Работа В. Балибердина и Г. Дюговской «Ангел», которая была создана в рамках международного фестиваля плетения (г. Новы Томысль, Польша, 2015 г.) получила III место (рис. 2, б) $[10$, с. 140]. Проект представлял собой ангела, который широко раскинул крылья. Работа поражает своими размерами - высота около 6 метров - и манерой исполнения. Эффект движения достигается художественным приемом, увеличением объема фигуры ангела снизу и уменьшением сверху, что подчеркивает намерение ангела подняться в небо.

Применяют технику плетения в своих работах украинские мастера Геннадий Титов [11] и Татьяна Ягодкина, которые более 10 лет создают артобъекты на международных пленэрах и фестивалях ленд-арта [12]. В течение нескольких лет авторы создали серию произведений в технике лозоплетения во время международных симпозиумов в Польше. Например, совместная композиция Г. Титова и Т. Ягодкиной «Святой огонь» размером 2,5х3 метра (дендропарк г. Болестрашице, Польша, 2019 г.) состоит из двух арт-объектов: «Огонь» Т. Ягодкиной и «Епископ» Г.
Титова (рис. 2, в). Создав два отдельных произведения мастера предложили артобъекты нового содержания, соединив их в общую композицию.
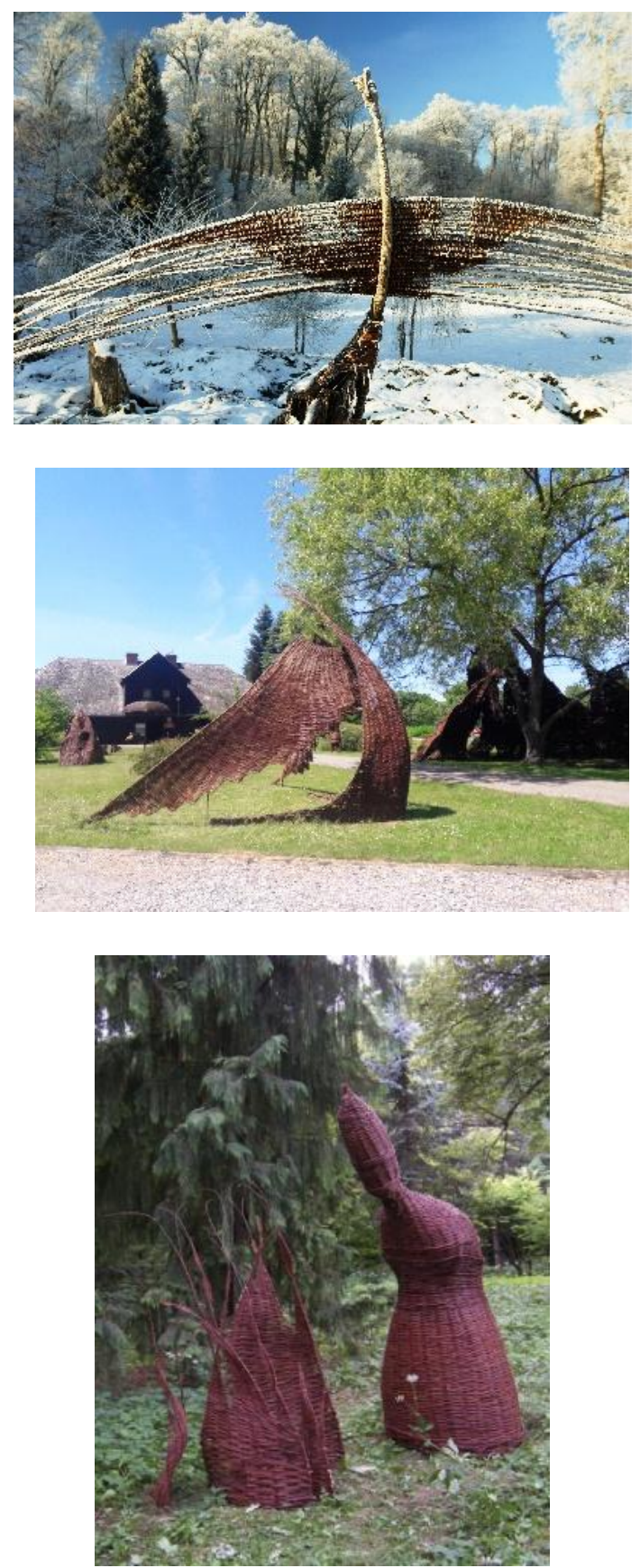


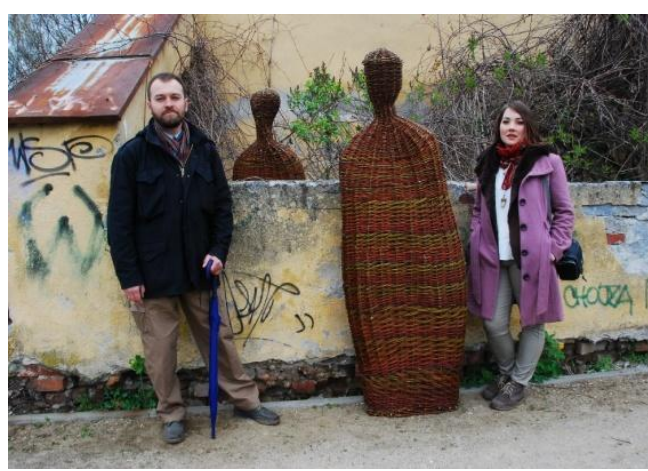

Рис. 2. Ленд-арт проекты украинских мастеров в технике лозоплетения:

a - «Эволюция», В. Балибердин, Г. Дюговская, г. Болестрашице, Польша, 2005 г.; б - «Ангел», В. Балибердин, Г. Дюговская, г. Новы Томысль, Польша, 2015 г.;

в - «Святой огонь», Г. Титов, Т. Ягодкина, г. Болестрашице, Польша, 2019 г.;

г - «Пан та пані», Г. Титов, Т. Ягодкина, г. Тарнобжег, Польша, 2014 г.

Необычна совместная композиция ленд-арта Г. Титова и Т. Ягодкиной «Пан та пані», расположенная на территории парка-дворца Тарновских (г. Тарнобжег, Польша, 2014 г.) (рис. 2, г). Идея произведения построена на демонстрации гендерных отношений, на противопоставлении мужского и женского образов. Эффект достигнут мастерами за счет удачного использования локации - стены, разделяющей главных героев -, а размер фигур, близкий к среднему росту человека, выбран авторами для достижения эффекта максимального отождествления с живыми людьми. Работа создана из лозы разных цветов, что придает ей дополнительную живописность и фактурность.

$$
\text { К популярным техникам в }
$$
искусстве ленд-арт также относится плетение из соломы, сена, камыша и других растительных материалов [7, с. 119]. К традициям этно-дизайна обращается в своих работах литовская мастерица ленд-арта Гинтвиле Гедрайтене (Gintvile Giedraitiene) [13]. Ee произведения представляют собой сплетенные из сена символические «Деревья» (г. Каунас, Литва, 2019 г.) (рис. 3, а). Как считает автор, произведения, созданные из растительных материалов, олицетворяют образы деревьев, прорастающих из живой природы. Ee арт-объекты являются образцами литовской этнокультуры, поскольку в своих произведениях мастер использует старинную технику плетения, а также этнические символы, узоры и образы, такие как: солярный знак, луна, солнце, птицы, заимствованные из народных мотивов. Гинтвиле Гедрайтене переосмысливает старинные образы, придавая им новое современное содержание. 

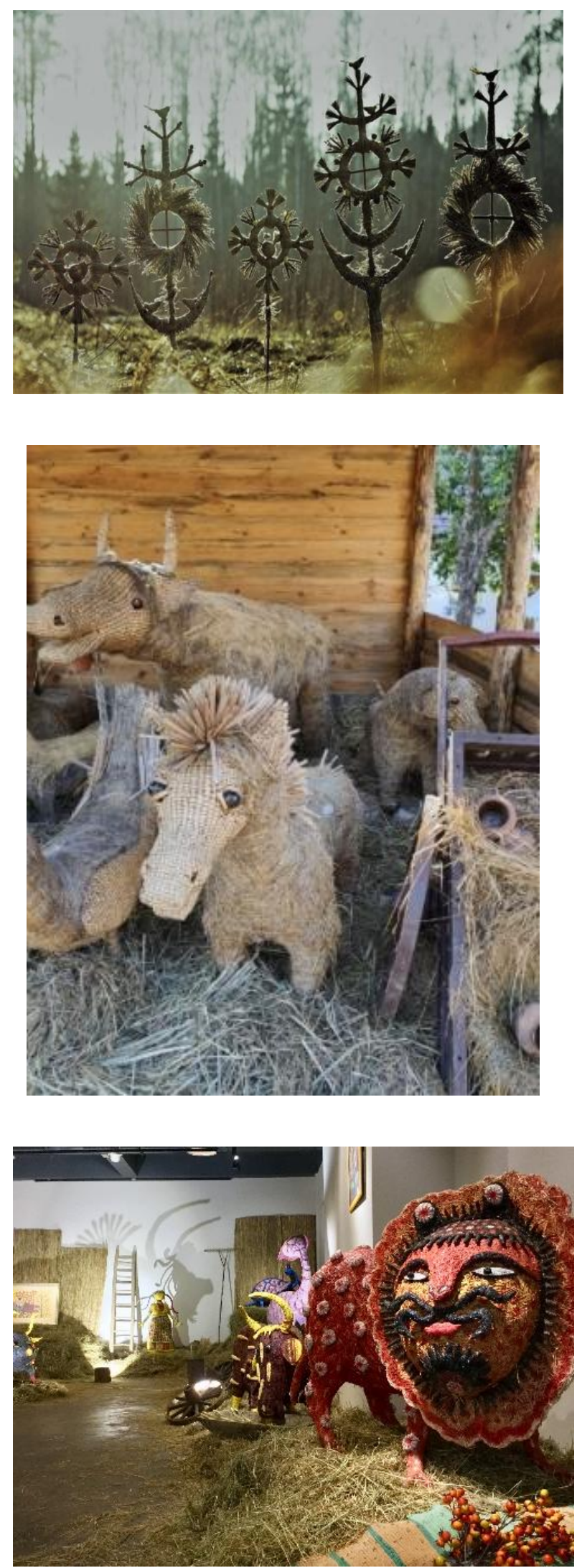

Рис. 3. Композиции ленд-арт в технике плетения: $\mathrm{a}$ - «Деревья», Г. Гедрайтене, г. Каунас, Литва, 2019 г.; б - «Плетеное чудо», П. Даниленко, г. Вышгород,

Украина, 2018 г.; в - часть композиции

«Наив ковчег», А. Шевчук, г. Киев,

Украина, 2012 г.

Большой вклад в популяризацию плетения из камыша в Украине внес народный мастер с Полтавщины Павел Даниленко, который создает в данной технике анималистические фигуры по мотивам украинских сказок и легенд. Одна из его ленд-арт композиций «Плетеное чудо», расположенная на территории Вышгородского историкокультурного заповедника (г. Вышгород, Украина, 2018 г.) демонстрирует анималистические образы героев фольклорного творчества украинского народа: соломенный бычок, котик, конек, овечка, свинка, петушок и коза (рис. 3, б). В этом арт-объекте различные образы объединены в единую композицию за счет использования одинаковых материала, техники создания работ и масштабности в соотношении образов друг к другу.

Применяет технику плетения из сена в своих ленд-арт объектах, под названием

«СІНОСКРИПТИ», украинский художник Алексей Шевчук. Он создал серию работ совместно с родственниками украинской художницы Марии Примаченко по мотивам ее творчества под названием «Наив ковчег» 
(Наїв ковчег) (г. Киев, Украина, 2012 г.) (рис. 3, в). Инсталляция представляет собой композицию, состоящую из стилизованной фигуры «МАЙСТРИНІ». Этот образ объединяет несколько понятий: женщина, философ, трипольская Баба. По замыслу художника «МАЙСТРИНЯ» является символом творчества, плодородия и красоты; а также, образом пастушки персонажей фантастических животных с картин Марии Примаченко. По словам автора Алексея Шевчука: «СІНОСКРИПТИ» - это закодированное в скульптуру из сена орнаментальное послание будущим поколениям, a выбранный для произведений материал (сено) воплощает многомерную структуру мироздания, состоящую из тонких нитей - травинок, которые связывают пространство» [14]. Также на плахте (юбке) фигуры «МАЙСТРИНІ» объединены орнаменты всех других фигур композиции. Дополнительная декоративность и поэтичность образов достигнута путем отделки работ цветом и узорами. Прототипами проекта «СІНОСКРИПТИ» стали живописные произведения художницы Марии Примаченко «Поліська болотяна зебра» (1986); «Звір гуляє» (1971); «Український поліський бичоктретячок гуляє у лісі та силу збирає»
(1983); «Черепаха ішла-ішла, оглянулась назад - ті самі квітки стоять, а вона на одному місці тупає» (1990); «Крилатий кінь» (1982); «Довгошия звірина чухається, не думає, що зима буде» (1977); «Корова отака дасть п’ять тисяч літрів молока» (1978); «Ушатка ізловила рака» (1983); «Довгонога чапля» (1986). Таким образом, своим творчеством А. Шевчук популяризирует не только технику плетения, но и украинское народное творчество.

В мировом художественном сообществе плетение из растительных материалов широко применяется среди мастеров ленд-арта. Данному направлению посвящены многие фестивали и симпозиумы. Среди таких мероприятий ленд-арта, сочетающее старинные традиции и современный подход в создании арт-объектов, можно выделить фестиваль искусства плетения из соломы «Wara art» (г. Ниигата, Япония, 2019). Фестиваль проходит на одном из крупнейших рисовых полей Японии, где рисовая солома используется мастерами для создания арт-объектов [15]. В прошлом рисовую солому перерабатывали и использовали для сельскохозяйственных нужд, но сообщество города Ниигата решила сделать использование соломы более эстетичным и привлекательным для 
туристов (рис. 4, а). С 2008 года по инициативе общины города Ниигата и Художественного

Университета

Мусашино (Musashino Art University) основан фестиваль плетения из соломы, который проходит ежегодно. Студенты творческих специальностей университета сотрудничают с жителями Ниигата для создания художественных произведений с использованием рисовой соломы и представляют это как ивент-событие. Во время фестиваля создается несколько арт-объектов, которые используют преимущественно зооморфные и мифологические образы (рис. 4, б). Артобъекты естественно вписываются в окружающий ландшафт за счет формы, цвета и фактуры. Таким образом, фестиваль «Wara art» демонстрирует использование искусства ленд-арт как способа содействия региональному туристическому развитию.

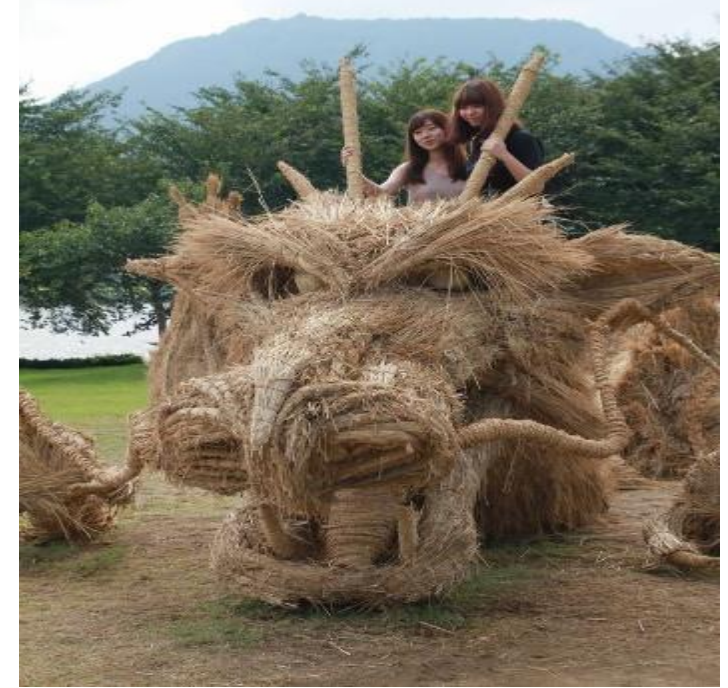

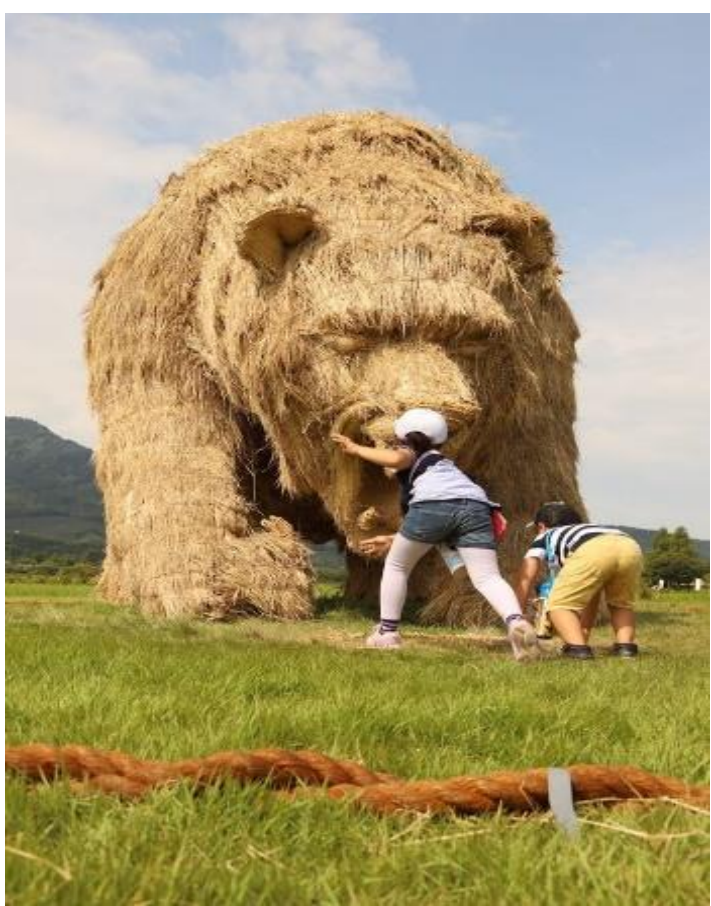

Рис. 4. Фестиваль «Wara art»: a «Дракон»; б - арт-объєкт «Медведь», ] Япония, 2019 г.

Выводы. Мастера ленд-арта активно используют различные техники для создания своих проектов: лозоплетение, плетение из соломы, камыша и других материалов. Произведения ленд-арта гармонично вписывают в окружающую среду используя материалы и способы создания, характерные для данной местности; применяют народные традиции и техники, характерные данному региону. Создание ленд-арт объекта никогда не наносится вред окружающей среде, наоборот, часто применяются материалы, которые подлежат утилизации, а мастера дают им шанс на вторую жизнь в качестве артобъекта. Произведения ленд-арта, 
выполненные с использованием этнических традиций, положительно воспринимаются зрителями и пользуются популярностью. Таким образом, мастера ленд-арта, применяя техники декоративно-прикладного искусства, популяризируют не только искусство и философию ленд-арта, а также культуру своей страны. Представленные в статье материалы могут быть использованы в научных исследованиях, посвященных развитию искусства ленд-арт, популяризации этнокультуры, а также для дальнейшего внедрения в авторских художественных проектах.

\section{Литература}

1. Гальчінська О.С., Гамалія К.О., Пашкевич К.Л. Аналіз творчості провідних митців ленд-арту XX століття. Art and design. 2019. №3. C. 48-57.

2. Сиваш I. О. Концептуальні засади етнодизайну в Україні. Вісник HAKKIM. 2018. № 3. C. 416-420.

3. Tafalla M. From Allen Carlson to Richard Long: The Art-Based Appreciation of Nature. Proceedings of the European Society for Aesthetics. 2010. vol. 2. C. 491515.

4. Литвинчук Н. Лозоплетіння на Сумщині: історія розвитку та сучасний стан. Етнічна історія народів Свропи. 2014. Вип. № 42, С. 68-78.
5. Сайт Anna \& the Willow. URL: http://www.annaandthewillow.co.uk/about/. (Last accessed: 08.01.2020).

6. Сайт Will Beckers. URL: http://www.willbeckers.com/Will_Beckers.h tml. (Last accessed: 08.01.2020).

7. Саєнко І.Ф. Історичні аспекти розвитку плетіння в Україні. Історія науки і техніки. 2015, вип. 7, С. 119-124.

8. Интервью О. Гальчинской с Галиной Дюговской. 21.01.2020.

9. Motyka K., Piórecki J., Nestorow R. Polska Ogrody i rezydencje. Libra Pl, 2007. 224 c.

10. Maciej P. Album III Światowego Festiwalu Wikliny i Plecionkarstwa w Nowym Tomyślu pod tytułem «Tutaj ludzie wyplataja swoje życie». Nowy Tomyśl. 2016. 264 c.

11. Интервью О. Гальчинской с Геннадием Титовым. 15.01.2010.

12. Интервью О. Гальчинской с

Татьяной Ягодкиной. 20.01.2020.

13. Страница Gintvile Giedraitiene. URL:

https://www.facebook.com/gintvile.giedraiti ene. (Last accessed: 08.01.2020).

14. Интервью О. Гальчинской с Алексеем Шевчуком. 22.01.2020.

15. Сайт фестиваля Wara Art. URL: http://www.city.niigata.lg.jp/nishikan/about/ kankou/wara-art/index.html_(Last accessed: $\underline{08.01 .2020)}$. 